\title{
AC 2009-288: ENTREPRENEURSHIP CURRICULA AND COMPETITIONS IN THE FACULTY OF ENGINEERING OF THE UNIVERSITY OF OTTAWA
}

\section{Claude D'Amours, University of Ottawa}

P.Eng., Ph.D.; Vice-Dean (Academic Affairs), Faculty of Engineering; Associate Professor, School of Information Technology and Engineering

\section{Claude Laguë, University of Ottawa}

P.Eng., ing., Ph.D.; Dean, Faculty of Engineering; Professor, Department of Mechanical Engineering

Frank Mellor, University of Ottawa

Executive-in-residence; Faculty of Engineering 


\title{
Entrepreneurship Curricula and Competitions at the Faculty of Engineering of the University of Ottawa
}

\begin{abstract}
Engineers Canada has identified entrepreneurship, innovation, and creativity as one of the five core sets of values for the engineering profession in Canada. According to the Canadian Academy of Engineering, creativity and innovation are indispensable qualities for engineers. Over the years, Canadian engineering schools have developed a number of curricular and extracurricular activities and programs in order to increase the exposure of engineering students to these important topics.

The Faculty of Engineering of the University of Ottawa is a medium-size (by Canadian standards $-1,800$ undergraduate and 600 graduate students; 115 regular faculty and 65 staff members) school that offers undergraduate and graduate programs in a number of engineering disciplines (biomedical, chemical, civil, computer, electrical, environmental, mechanical, software) and in computer science. Because of the bilingual nature of the University of Ottawa, students can choose to complete their studies in either one, or both, of Canada's official languages. At the undergraduate level, the Faculty offers an option in engineering management and entrepreneurship in six (6) of its eight (8) engineering programs. In 2006, the Faculty established the \$2-M Entrepreneurship and Innovation Endowment Fund (EIEF), thanks to an initial \$1-M donation from an anonymous alumnus. Operating under the guidance of an expert Advisory Board, the EIEF has allowed the Faculty to create a bi-annual lecture series on entrepreneurship and innovation (Entrepreneurship Bridges Lecture Series) as well as two entrepreneurship competitions for undergraduate and graduate students respectively.
\end{abstract}

\section{Introduction}

Entrepreneurship has long been recognized as a key contributor to economic growth (Hulsey et al. 1986; Wadhwa et al. 2008). Successful entrepreneurship ventures rely on creativity and innovation, where innovation must be considered as the combination of both invention and commercialization (Brzustowski 2006). Because of their educational background that increasingly includes exposure to business, communications, humanities, and social sciences in addition to the traditional scientific and technical components, engineering professionals are uniquely positioned to engage into innovation ventures (Canadian Academy of Engineering 1998). A well-known example of a successful entrepreneur in Canada who has relied on his engineering education to achieve world-scale success is Mr. Mihalis Lazaridis, founder and coCEO of the technology giant Research in Motion. Quoting Brzustowski (2008), 'Canada has achieved excellence in science and engineering just as this is becoming the key to prosperity.' Therefore, it is not surprising that Engineers Canada has identified 'entrepreneurship, innovation, and creativity' as one of the five core sets of values for the engineering profession in Canada (Engineers Canada 2009). 
As it has been the case in the United States of America (re. Standish-Kuon and Rice 2002; Ochs et al. 2001), Canadian engineering schools have responded to this call for action coming from the profession that they serve in a variety of ways that include academic and/or extra-curricular components:

- The Xerox Centre for Engineering Entrepreneurship \& Innovation at McMaster University offers a Master of Engineering Entrepreneurship \& Innovation degree (McMaster University 2009). That program allows students to develop their own start-up project at the same time that they complete the academic requirements associated to this degree. In 2007, two technology projects from the Xerox Centre were selected within the scope of Canada's Top 10 competition for promising start-up companies.

- The Faculty of Applied Science and Engineering of the University of Toronto offers a graduate program (certificate) named ELITE (Entrepreneurship, Leadership, Innovation, and Technology in Engineering) that can be included within its existing Master of Engineering programs (University of Toronto 2009).

- In collaboration with the Edwards School of Business, the College of Engineering at the University of Saskatchewan has implemented an Engineering Entrepreneurship Option (EEO) consisting of seven courses in addition to the normal content of its undergraduate engineering programs (University of Saskatchewan 2009). The EEO culminates with an Engineering Entrepreneurship capstone course offered by the College of Engineering that draws upon case studies and personal experiences of engineers-entrepreneurs.

Founded in 1848 and located in Canada's National Capital region of Ottawa - Gatineau, the University of Ottawa - Canada's University - is the largest bilingual university in the country offering undergraduate and graduate programs of studies in English, French, or both languages to more than 36,000 students. With its 1,800 undergraduate and 600 graduate students, 115 regular faculty, and 65 staff members, the Faculty of Engineering at the University of Ottawa is a medium-size (by Canadian standards) school that offers undergraduate and graduate programs in a number of engineering disciplines (biomedical, chemical, civil, computer, electrical, environmental, mechanical, software) as well as in computer science. At the undergraduate level, the Faculty has been offering an option in engineering management and entrepreneurship for a number of years that is currently available in six (6) of its eight (8) engineering programs.

Building on its past experience in the area of entrepreneurship, the Faculty established the \$2-M Entrepreneurship and Innovation Endowment Fund (EIEF) in 2006, thanks to an initial \$1-M donation from an anonymous alumnus. Operating under the guidance of an expert Advisory Board, the EIEF has allowed the Faculty to create a bi-annual lecture series on entrepreneurship and innovation (Entrepreneurship Bridges Lecture Series) as well as two entrepreneurship competitions for undergraduate and graduate students respectively. 


\section{Option in engineering management and entrepreneurship}

In the 1970s, approximately two-thirds of all Canadian engineers occupied supervisorymanagement positions for more than half of their professional careers. In order to better prepare University of Ottawa engineering students for this type of employment, an engineering management option was added to the curriculum at that time. Furthermore, a 5-year engineering management program was created in 1980.

The option consisted of two management courses (Introduction to Management and Process of Management), one computer science course (Data Processing for Engineering Management), two mathematics courses (Introduction to Probability and Introduction to Statistics) and two Management Science courses (Introduction to Management Science and Industrial Operations Management). Students registered in this option were excused from four non technical elective as well as one mathematics courses that student in the "regular" programs were required to take.

The 5-year Engineering Management Program was intended for students that had completed a four year Engineering program with the management option described above. It consisted of additional management courses. Students completing this program received a Bachelor's of Applied Science in Engineering Management with specialization in one of the four branches of Engineering offered at the University of Ottawa at the time, namely Civil, Electrical, Mechanical or Chemical. This program has evolved into the Master's of Engineering Management that is currently offered by the Faculty of Engineering of the University of Ottawa.

The Engineering Management option has been modified over the years. Renamed the Engineering Management and Entrepreneurship option, it has been streamlined so that its students need not complete more credits than student not enrolled in the option. For example, Civil Engineering students in the Management and Entrepreneurship option must take five courses (15 credits). Four of these courses are offered by the University of Ottawa's Telfer School of Management. They are ADM1100 Introduction to Business Management, ADM2320 Marketing, ADM2340 Financial Accounting, and ADM3313 Entrepreneurial Mind: New Venture Creation. The fifth course is the Civil Engineering course CVG4173 Construction Management.

Students enrolled in this option are exempt from 6 credits of non technical electives that the students in the "regular" option must complete. Students in the "regular" option must also take three courses of technical electives, while the students in the Management and Entrepreneurship option must take the CVG4173 course as their only technical "elective". As a result, students in the Management and Entrepreneurship option and students in the "regular" option must complete 132 credits to obtain their Bachelor's of Applied Science in Engineering.

A recent innovation in this option is the creation of the ADM3313 course. The course teaches, among other things, how to create a start-up company, technology assessment, the business planning process and how to create a business plan. Local entrepreneurs and professionals bring their experiences directly to the classroom. 
The Faculty of Engineering collaborates with the Telfer School of Management to maintain the option and to make sure that it continues to meet the students' needs. If the Faculty of Engineering wishes to change the content of the option, by removing one course and adding another, we make the request to the Telfer School of Management. Once approved, then the change must be approved by the Faculty Council as well as the university's Council on Undergraduate Studies. Once approved by these bodies, the Senate must ultimately approve the change. Should the Telfer School of Management wish to change the course content of one of the courses offered in the option, they seek the consent of the Faculty of Engineering before implementing any changes.

Over the last five years, roughly 350 students have completed the Management and Entrepreneurship option as part of their degree requirements. This represents approximately $20 \%$ of all graduates of our programs during that period of time.

\section{Entrepreneurship and Innovation Endowment Fund (EIEF)}

Following his appointment as Dean of the Faculty of Engineering in the summer of 2006, Dr. Laguë initiated discussions with an alumnus of the Faculty who was interested in giving back to his alma mater to support ventures associated with entrepreneurship and innovation and that would directly benefit students of the Faculty. His \$1-M donation coupled with a similar matching contribution by the University of Ottawa has allowed for the establishment of the Entrepreneurship and Innovation Endowment Fund (EIEF) in the Faculty of Engineering that was officially launched in March 2007. Since 2007, the EIEF has featured prominently in the annual fundraising strategy of the Faculty.

Revenues from the EIEF are currently supporting two main initiatives: a biannual series of conferences on entrepreneurship and innovation (Entrepreneurship Bridges Lecture Series) and two student competitions in entrepreneurship and innovation for undergraduate and graduate students of the Faculty of Engineering respectively. The Faculty has established an Advisory Board that includes two (2) undergraduate and one (1) graduate students, one (1) professor from the Faculty, three (3) professors from the Telfer School of Management of the University of Ottawa, the Director of the Technology Transfer and Business Enterprise service of the University of Ottawa, as well as eight (8) businesspersons from the Ottawa - Gatineau region, including some alumni of the Faculty who are successful entrepreneurs. The mandate of the Advisory Board is to assist the Faculty in three key areas associated to the EIEF: program and activity development, promotion, and funding.

\section{Entrepreneurship Bridges Lecture Series}

The purpose of the biannual Entrepreneurship Bridges Lecture Series is to increase the awareness of students, as well as of faculty and staff, to entrepreneurship and innovation. The fact that engineers and scientists play a pivotal role in developing new ideas and technologies that can be turned into new commercial products or services is well known within our faculty community. This lecture series constitutes one means to increase the exposure of our students, 
faculty, and staff to issues that go beyond the scientific and technical aspects of engineering and computer science.

Two Entrepreneurship Bridges lectures are held each year in March and in September. Until now, they have been scheduled early in the morning (e.g. from 7:00 to 9:00) along the successful model used by many business associations in the Ottawa - Gatineau area such as the Ottawa Centre for Research and Innovation (OCRI). Past Entrepreneurship Bridges lecturers have included:

- Dr. Bruce M. Firestone (March 2007): Civil engineer; founder of the Ottawa Senators NHL franchise and of the ScotiaBank Place arena; real estate broker and developer; currently entrepreneur-in-residence at the Telfer School of Management.

- Mr. Tom Goguen (September 2007): Alumnus of the Faculty (electrical engineering); has held important technical and management positions at Apple Computers, GridIron Sofware, and Sun Microsystems.

- Mr. Jim Roche (March 2008): Electrical engineer; has held important technical and management positions at Canadian Microelectronics Corporation, Newbridge Networks Corporation, and Tundra Semiconductor Corporation.

- Mr. Richard L'Abbé (September 2008): Alumnus of the Faculty (mechanical engineering); founder of the bomb protective gear and equipment manufacturer Med Eng Systems Inc.

- Sir Terence Matthews (March 2009): Electrical engineering; founder of some 80 hightechnology and investment companies in Canada and in the United Kingdom, including Mitel, Newbridge Networks, and Wesley Clover

\section{$\underline{\text { Undergraduate and Graduate Prize in Entrepreneurship and Innovation (PEI) Competitions }}$}

Since 2007 - 2008, the Faculty of Engineering has been organizing two competitions in entrepreneurship and innovation; the Undergraduate Prize in Entrepreneurship and Innovation (UPEI) and the Graduate Prize in Entrepreneurship and Innovation (GPEI). The EIEF provides for the monetary awards and the operating costs of the competitions. The goal of both competitions is to provide financial awards $(\$ 45,000$ in total) as well as business skills and mentorship to graduate and undergraduate students who engage into entrepreneurship and innovation projects.

Overview of the $2007-2008$ competitions

The first competitions were held during the 2007 - 2008 academic year. Competitors submitted an expression of interest (EOI) in which were presented the members of their teams along with an executive summary of the innovative product or service being proposed. Ten (10) groups, totaling 31 students, proposed projects for the UPEI competition, while six (6) groups, totaling seven (7) graduate students, made similar proposals for the GPEI. All groups were then asked to submit short summaries of their projects that consisted of their "elevator pitch" followed by an executive summary of the technology. Also required was a market overview detailing the potential clients and possible competitors as well as a description of the financial needs, ability to execute, and risks. The prize subcommittee reviewed the summaries and the best proposals were 
then invited to present a business plan. Presentations were judged on their business model, sales cycle, ability to identify competitors and risk, their competitive advantages over others in the market and their financial plans.

A project on an innovative software based piano teaching tool won first prize in the UPEI. Second and third prize were awarded for projects respectively dealing with motion detection and autonomous flight control marketed for mapping applications. In the GPEI, a project for a noninvasive heparin measurement system was awarded first prize. Second prize was awarded to a process of using biodiesel for polymerization and third prize went to a noninvasive blood glucose monitor.

Students competing in our 2007 - 2008 competitions were able to leverage the experience into additional prizes in other entrepreneurship and innovation competitions. One of them, the Technology Venture Challenge (TVC - http://www.techvc.org/), is Ottawa's biggest entrepreneurship competition for post-secondary students allowing them to showcase their innovative ideas. The team with the best technology business case wins a $\$ 10,000$ cash prize. Two runner-up teams each win \$5,000. The TVC is a member of MIT's Global network of university business plan competitions. The first and third place finishers in the 2007-2008 GPEI competitions combined their efforts and received one of the runner-up prizes at the 2008 TVC.

The third place finishers in the UPEI also presented their project at the 2008 student paper night of the Ottawa Chapter of Professional Engineers Ontario (PEO) where they received the Best Innovation / Commercial Application prize. Furthermore, the winners of the UPEI competition, with the help of OCRI, have started a company to market their software-based PianoLink system.

Overview of the $2008-2009$ competitions

Minor adjustments to the two competitions (deliverables, timelines) were implemented in 2008 2009. In addition, an online tool for the submission, review, and evaluation of the written student business plans was adapted for the competitions and made available to the students as well as to their mentors and to the judges. It is worthwhile to mention that this tool (Review Room) has been developed by a company (chide it - http://www.chide.it) founded by a young alumnus (Mr. Aydin Mirzaee) of our faculty - a good example of technological entrepreneurship to which the participants to the competitions can easily relate to!

Eight (8) undergraduate students / student teams accounting for a total of 23 students and collaborators as well as 12 graduate students / student teams accounting for a total 19 students and collaborators did submit EOI at the beginning of the 2008 - 2009 UPEI and GPEI competitions. Of that number, a total of 12 teams (5 undergraduate and 7 graduate) completed and submitted written business plans in time for the March 6, 2009 deadline. The business plans were reviewed, evaluated, and ranked by a panel of judges from academia and industry according to 14 criteria: opportunity identification, technology advancement, value proposition, market definition, total market size, addressable market, potential customers, channels to market, competitors, barriers to entry, exit strategy, key milestones, financial plan, and risk assessment. At the time of the writing of the final version of this paper, all 12 teams had been invited to make oral presentations of their business cases to the judging panel at the end of March 2009. The 
combined outcomes of the written business plan evaluations and of the evaluations of these oral presentations will serve to determine the recipients of the first- $(\$ 10,000)$, second- $(\$ 7,500)$, and third-place $(\$ 5,000)$ winners in each of the two competitions categories (UPEI and GPEI).

Support to participating students

To strengthen the quality of the learning experience, various types of support are provided to the participating students in partnership with the local Ottawa business community. Throughout the process, students have access to consulting to assist them in preparing for the competition, creating their business plan and final presentation and in developing their understanding of business/venture creation. This consulting is provided in partnership with the Ottawa Centre for Research and Innovation - Entrepreneurship Centre and with the assistance of an Executive in Residence.

The Ottawa Centre for Research and Innovation (OCRI) is Ottawa's leading member-based, nonprofit economic development corporation for fostering the advancement of the region's globally competitive knowledge-based institutions and industries. OCRI delivers its economic development services through a unique partnership with the City of Ottawa, where the City and OCRI, through its members set the strategy and manage the programs that move Ottawa's economy forward. The Entrepreneurship Centre (EC) is an initiative of OCRI, dedicated to helping Ottawa entrepreneurs make educated decisions about starting and growing their businesses. The Executive in Residence at the Faculty of Engineering is a retired Telecoms R\&D executive who volunteers his time to support the student competition.

To augment the one-on-one consulting support, the OCRI - EC holds workshops throughout the competition. Each workshop focuses on an essential element of entrepreneurship. Students also have access to their extensive library of support materials. In addition to the general consulting support available, each team is offered the opportunity to interact with a mentor for the duration of the competition. The mentors are professionals from the local business community who volunteer their expertise to help the students get the most out of their experience. For those students who are interested in pursuing the entrepreneurship opportunity further, the OCRI - EC offers continued support in entering other regional competitions and in potentially starting up a business venture.

\section{Summary}

In response to the call for action coming from Canadian engineering stakeholders, the Faculty of engineering at the University of Ottawa has implemented a two-prong approach that includes both academic and extra-curricular components in order to increase the exposure of engineering students to entrepreneurship and innovation. The first component consists of an option in management and entrepreneurship that can be incorporated into most undergraduate engineering programs offered by the Faculty. Over the last five years, about $20 \%$ of the graduates of these programs have completed this option. In 2007, the Faculty of Engineering has established a \$2$M$ Entrepreneurship and Innovation Endowment Fund (EIEF) that is providing financial support to two extra-curricular activities in entrepreneurship for students of the Faculty: A bi-annual 
distinguished lecture series and two annual entrepreneurship competitions for undergraduate and graduate students respectively. The first edition of these competitions held in 2007-2008 featured 16 different business projects involving more than 30 students of the Faculty. Some of these students went on to compete in other entrepreneurship competitions outside the University and at least one team has established a start-up company to continue the development and commercialization of the innovative idea that they presented to the Faculty's competition.

\section{References}

Brzustowski, T. 2008. The way ahead-Meeting Canada's productivity challenge. The University of Ottawa Press: Ottawa, ON, Canada.

Brzustowski, T. 2006. Innovation = Invention + Commercialization: A Systems Perspective. Optimum Online The Journal of Public Sector Management 36 (3) (available at www.optimumonline.ca).

Canadian Academy of Engineering. 1998. Wealth through Technological Entrepreneurship; Challenges and Opportunities for Canadians. Canadian Academy of Engineering: Ottawa, ON, Canada (available at http://www.acad-eng-gen.ca/publis/e/Wealth_an.cfm).

Engineers Canada. 2009. A Vision for the Engineering Profession. Engineers Canada: Ottawa, ON, Canada (available at http://www.engineerscanada.ca/e/files/visiondoc_eng.pdf).

Hulsey, L., L. Rosenberg, and B. Kim. 2006. Seeding Entrepreneurship Across Campus: Early Implementation Experiences of the Kauffman Campuses Initiative. Final report to the Ewing Marion Kauffman Foundation. Mathematica Policy Research, Inc: Princeton, NJ.

McMaster University. 2009. Xerox Centre for Engineering Entrepreneurship \& Innovation. McMaster University: Hamilton, ON, Canada (available at http://www.businessinnovation.ca/).

Ochs, J.B., T.A. Watkins, and B.W. Boothe. 2001. Creating a Truly Multidisciplinary Entrepreneurial Educational Environment. Journal of Engineering Education 90 (4): 577 - 583.

Standish-Kuon, T. and M.P. Rice. 2002. Introducing Engineering and Science to Entrepreneurship: Models and Influential Factors at Six American Universities. Journal of Engineering Education 91 (1): 33 - 39.

University of Saskatchewan. 2009. Engineering Entrepreneurship Option. University of Saskatchewan: Saskatoon, SK, Canada (available at http://engrwww.usask.ca/main/student/eeo/EEO.pdf).

University of Toronto. 2009. Series of Courses in Entrepreneurship, Leadership, Innovation and Technology in Engineering (ELITE). University of Toronto: Toronto, ON, Canada (available at http://www.engineering.utoronto.ca/explore/elite.htm).

Wadhwa, V., R. Freeman, and B. Rissing. 2008. Education and Tech Entrepreneurship. Ewing Marion Kauffman Foundation: Kansas City, MO. 